\title{
Effect of nitrogen loading rates on nitrogen removal by using a biological filter proposed for ventilated improved pit latrines
}

\author{
*M. A. A. Coetzee; M. P. R. Van der Merwe; J. Badenhorst \\ Department of Biotechnology and Food Technology, Tshwane University of Technology, Nelson Mandela Drive 175, \\ Arcadia, South Africa \\ Received 13 January 2010; $\quad$ revised 16 October 2010; accepted 1 February 2011; $\quad$ available online 1 March 2011
}

\begin{abstract}
Pit latrines are the most frequently used sanitation systems in developing countries because of weak infrastructure and poor economic wealth. A modified ventilated improved pit latrine, with a biological filter beneath is proposed to stabilize and to remove the bulk of the nitrogen from the liquid phase. Although the hydraulic loading rate in the proposed biological filter system was calculated to be ca $36 \mathrm{~L} / \mathrm{m}^{2} / \mathrm{d}$, significantly lower than the rates that are typical applied in standard rate biological filters (in the range of $1000-4000 \mathrm{~L} / \mathrm{m}^{2} / \mathrm{d}$ ) used to treat domestic wastewater; the total Kjeldahl nitrogen and chemical oxygen demand concentrations are significantly higher in faecal sludge, namely $3-5 \mathrm{~g} / \mathrm{L}$ and $20-50 \mathrm{~g} / \mathrm{L}$, respectively compared to $c a 60 \mathrm{mg} / \mathrm{L}$ and $500 \mathrm{mg} / \mathrm{L}$ in standard rate biological filters. The biological filter was operated at nitrogen loading rates of 72, 145, 290 and $435 \mathrm{~g} / \mathrm{m}^{2} / \mathrm{d}$, respectively, until stable state conditions were obtained. The biological filter showed effective nitrogen removal between 72 and $434 \mathrm{~g} / \mathrm{m}^{2} / \mathrm{d}$ and the best total nitrogen removal was obtained at $145 \mathrm{~g} / \mathrm{m}^{2} / \mathrm{d}$, namely $92 \%$. These results suggest that it should be possible to remove nitrogen effectively using a biological filter beneath a modified ventilated improved pit latrine.
\end{abstract}

Keywords: Ammonia volatilization; Biomass assimilation;Denitrification; Nitrification; Urea

\section{INTRODUCTION}

Globally, 2.6 billion people do not have access to adequate sanitation (WHO, 2009). In Africa, 234 million people have no access to any sanitation systems (WHO and UNICEF, 2008). Because of weak infrastructure and poor economic wealth, pit latrines are the most frequently used sanitation systems (Pickford, 1995). Depending on the soil type, specifically the permeability, leachate from a pit latrine could contaminate the groundwater and whereas microbial contaminants will decrease over time, chemical contaminants could persist (DWAF, 2003; Nwuche and Oguji, 2010). This is especially true for the high concentrations of nitrogen and organic matter contained in the faecal sludge (3-5 g N/L and 20-50 g COD/L, respectively) (Montangero and Strauss, 2002; $\mathrm{Lu}$ and Huang, 2010; Cheng et al., 2011). The composition of the biodegradable nitrogen and organic compounds in the leachate will change as it moves through the soil due to natural biological processes that occur (Babel et al., 2009). Although COD is

*Corresponding Author Email: coetzeemaa@tut.ac.za

Tel.: +12-382 6234; Fax: +12-382 6354 reduced, research has shown elevated concentrations of nitrogen species specifically nitrate in groundwater surrounding pit latrines (Tredoux et al., 2000; Zingoni et al., 2005; Dzwairo et al., 2006; Okafor and Opuene, 2007; Chenini and Khemiri, 2009). Nitrate poses a serious health risk to the users of the water source (Nouri et al., 2008; Suthar et al., 2009), especially young babies who are bottle fed as it causes the condition methaemoglobinaemia (Terblance, 1991; Tredoux et al., 2000). Some researches also indicate a possible link between even low nitrate concentrations and gastric cancer (WHO, 1992).

The nitrogen content of faecal matter (urine and faeces) is very high. The biggest contributor to the total nitrogen excreted is the urine fraction, contributing $93 \%$ to the total nitrogen concentration (Geigy, 1962). In this fraction $84 \%$ consists of urea-nitrogen, which is readily converted to ammonia (Geigy, 1962). The faecal fraction contributes to undigested nitrogen fractions (in smaller amounts) (WHO, 2006). The amount of nitrogen that humans excrete daily depends on the amount of proteins consumed and it varies in 
different countries from as low as $2.1 \mathrm{~kg}$ nitrogen per year in Haiti, $3.4 \mathrm{~kg}$ nitrogen per year in South Africa up to $4.0 \mathrm{~kg}$ nitrogen per year in China (WHO, 2006) due to the differences in eating habits. The concentration of the nitrogen in the urine depends on the climatic conditions, the amount of liquid consumed and the level of personal activity. The amount of liquid excreted by humans daily varies between $0.8-1.6 \mathrm{~L}$ (WHO, 2006). According to WHO (2006) a good estimate of the concentration of nitrogen in the urine at excretion, will be in the range of $3-7 \mathrm{~g} \mathrm{~N} / \mathrm{L}$. Assuming a liquid excretion rate of $1.5 \mathrm{~L}$ per person and an average nitrogen concentration of $5 \mathrm{~g} \mathrm{~N} / \mathrm{L}$, the nitrogen loading rate on a pit latrine will be $180 \mathrm{~g} \mathrm{~N} / \mathrm{m}^{2} / \mathrm{d}$ (assuming that 6 persons use the pit latrine daily and that the useful surface area in the pit will be $0.25 \mathrm{~m}^{2}$ ). Currently no treatment of pit latrine content is done on-site in rural and remote areas and when the pit is full, it is closed and a new pit is installed (Koné and Strauss, 2004). These pits, from start of use, constantly release high nitrogen leachate into the soil (depending on the soil conditions). A simple yet effective treatment process for ammonia removal is the use of standard rate biological filters, packed with rock media. However, when comparing the daily loading rates of a standard rate biological filter and a pit latrine, there are marked differences. The typical organic loading rate on a standard rate biological filter that treats domestic waste water is in the range of 0.07 to $0.22 \mathrm{~kg} \mathrm{BOD} / \mathrm{m}^{3} / \mathrm{d}$ and the nitrogen loading rate is in the range of 0.2 to $1.0 \mathrm{~g}$ $\mathrm{N} / \mathrm{m}^{2} / \mathrm{d}$ (MetCalf and Eddy, 2003). The nitrogen loading rate on a standard rate biological filter is therefore considerably lower (between 180 to 900 times lower) than the $180 \mathrm{~g} \mathrm{~N} / \mathrm{m}^{2} / \mathrm{d}$ loading rate experienced in a pit latrine. Similarly, organic loading rates are higher than what is required to achieve nitrification as nitrifying bacteria are autotrophic and have to compete with heterotrophic bacteria for space in the filter, so they usually only become well established when the concentration of the organic matter starts to decrease in the filter (Grady and Lim, 1980). According to MetCalf and Eddy (2003) very low organic loading rates, between 0.05 to $0.10 \mathrm{~kg} \mathrm{BOD}_{5} / \mathrm{m}^{3} / \mathrm{d}$, are required to achieve between $85-95 \%$ nitrification, while the organic loading rate in a pit latrine will be about $0.3 \mathrm{~kg} \mathrm{BOD} /$ $\mathrm{m}^{3} / \mathrm{d}$. However, the hydraulic loading rate, ca $36 \mathrm{~L} / \mathrm{m}^{2} /$ $\mathrm{d}$, is much lower than a typical standard rate biological filter that treats domestic wastewater, receiving 1000 $4000 \mathrm{~L} / \mathrm{m}^{2} / \mathrm{d}$ (MetCalf and Eddy, 2003). These lower hydraulic loading rates lead to slower trickling through the filter and consequently longer retention times that should be favourable in the treatment process. Evidence of the application of biological filters to treat VIP effluent on-site could not be found and therefore a new modified VIP system is proposed, where the faecal sludge in the pit will be allowed to leach into a biological filter (Fig. 1). The filter will be packed with stones. The vent pipe will be fitted with an extraction fan to induce a draft through the filter. Thus, all the liquid that seeps from the top part of the pit will be treated in the biological filter. The nitrogen will be removed by a combination of nitrification and denitrification processes.

The purpose of this investigation was to evaluate the effect of different nitrogen loading rates on a laboratory scale, biological filter (with dimensions proportional to that of the proposed system) loaded with nitrogen, at the same application rates as would be applied to the proposed process. The research for this project was conducted at Tshwane University of Technology during the period 2006 to 2009.

\section{MATERIALS AND METHODS}

\section{Biological filter set-up}

The biological filter consisted of a PVC column, 150 $\mathrm{mm}$ in diameter and $1500 \mathrm{~mm}$ in length. The filter was packed with stones, $10-20 \mathrm{~mm}$ in diameter. The synthetic waste medium was fed intermittently to the biological

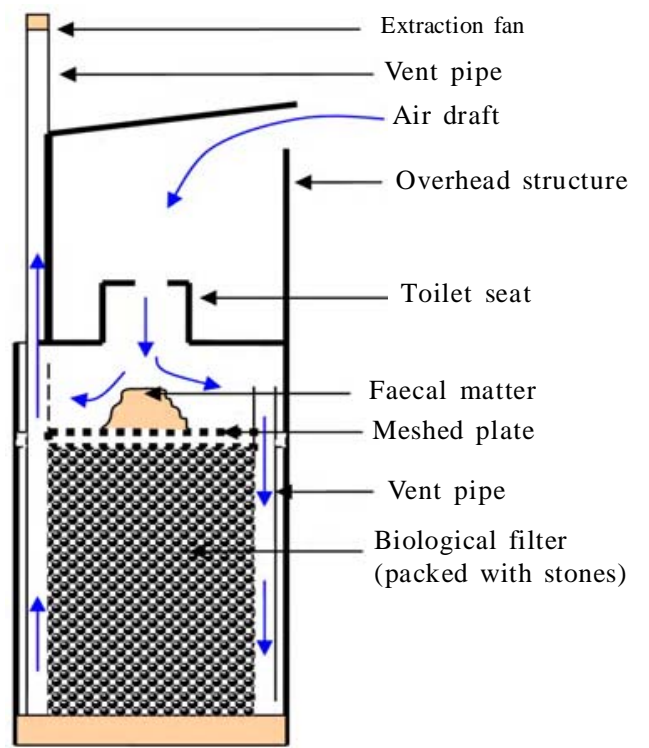

Fig. 1: A schematic layout of the proposed modified ventilated improved pit latrine 

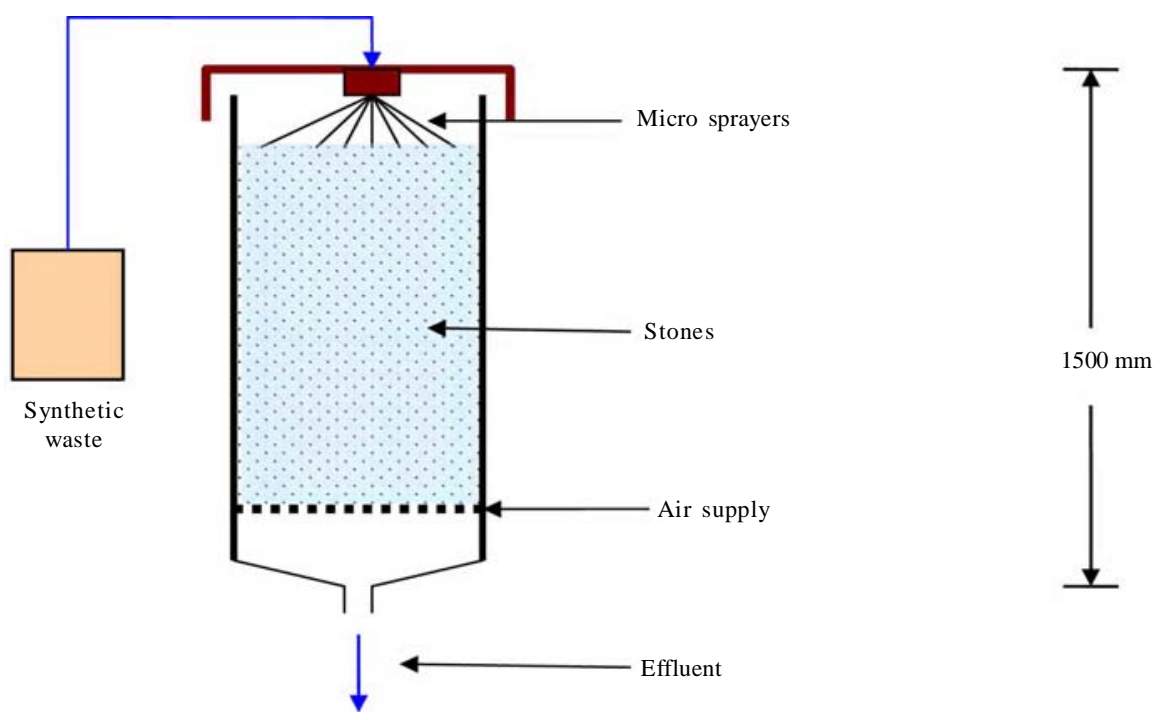

Fig. 2: Schematic layout of the biological filter

filter by means of a diaphragm dosing pump (Model: Alldos M205). The pump was controlled by an electronic timer, which switched the pump on for 30 seconds, every hour. The medium was distributed through micro sprayers over the stones onto the biological filter (Fig. 2). Air was supplied by means of a compressor (Model: Fini, 100) through a network of perforated perspex pipes at a rate of $1 \mathrm{Nm}^{3} / \mathrm{h}$.

The composition of the synthetic waste medium

Fresh medium was prepared daily. The synthetic waste medium contained $16 \mathrm{~g} / \mathrm{L}$ glucose equal to a COD concentration of $17100 \mathrm{mg}$ COD/L. The $\mathrm{pH}$ was buffered to $\mathrm{pH} 7$ with $1.8 \mathrm{~g} / \mathrm{L}$ potassium dihydrogen phosphate, and $2.8 \mathrm{~g} / \mathrm{L}$ disodium hydrogen phosphate. The phosphate salts were also used to ensure sufficient phosphorous to sustain unrestricted microbial growth in the biological filter. Nitrogen was added in the form of urea. The urea concentration added during the different trials was $4.3 \mathrm{~g} / \mathrm{L}, 8.6 \mathrm{~g} / \mathrm{L}, 17.2 \mathrm{~g} / \mathrm{L}$ and $25.8 \mathrm{~g} / \mathrm{L}$, this was equal to $2 \mathrm{~g} \mathrm{~N} / \mathrm{L}, 4 \mathrm{~g} \mathrm{~N} / \mathrm{L}, 8 \mathrm{~g} \mathrm{~N} / \mathrm{L}$ and $12 \mathrm{~g} \mathrm{~N} / \mathrm{L}$, respectively.

Operational conditions in the biological filter

The biological filter was operated at a dosing rate of $650 \mathrm{~mL} / \mathrm{d}$. That is equal to a hydraulic loading rate of $35.7 \mathrm{~L} / \mathrm{m}^{2} / \mathrm{d}$. The biological filter was operated at the following nitrogen concentrations: 2 g N/L, 4 g N/L, 8 g $\mathrm{N} / \mathrm{L}$ and $12 \mathrm{~g}$ N/L (nitrogen loading rates of 72, 145, 290 and $435 \mathrm{~g} / \mathrm{m}^{2} / \mathrm{d}$, respectively). When the nitrogen concentration was changed the reactor was operated until stable state conditions were obtained. Stable state conditions were based on stable performance of the biological filter with regards to ammonia, nitrite and nitrate concentrations (three to four weeks of comparable results) in the effluent.

\section{Monitoring of the effluent composition}

The $\mathrm{pH}$ (Orion Model 410A) and conductivity (Hach Model Sension 6) of the effluent from the biological filter, as well as the volume throughput were determined daily in all the trials. The effluent from the different trials were also analysed at least once a week for COD, TKN, nitrate, nitrite and ammonia according to Standard Methods (APHA et al., 2005).

\section{High concentrations of nitrate and nitrite}

Higher concentrations of nitrate and nitrite were determined with an ion chromatograph (76I Compact IC from Metrohm). A Metrosep A Supp 3 column (6.1005.320) was used. The sample loop was $20 \mu \mathrm{L}$ and the flow rate through the column was $1.0 \mathrm{~mL} / \mathrm{min}$ with a mixture of $1.7 \mathrm{mM} \mathrm{NaHCO}_{3}$ and $1.8 \mathrm{mMNa}_{2} \mathrm{CO}_{3}$ as eluents (APHA et al., 2005).

\section{Low concentrations of nitrate and nitrite}

Lower concentrations of nitrate and nitrite were determined with colorimetric methods. The salycilate 
method was used for nitrate analyses (Miller and Wideman, 1956). An aliquot of the sample, treated with sodium salicylate was evaporated on top of a water bath. The dried sample was resuspended with concentrated sulphuric acid and diluted with distilled water before a $50 \%$ sodium hydroxide solution was added for colour development. Thereafter the sample was transferred, quantitatively, to a volumetric flash and the absorbance was read at a wavelength of 410 $\mathrm{nm}$ on a spectrophotometer (Hach model: DR2000). The concentration was determined with the aid of a calibration curve. The nitrite concentration was determined colorimetrically by addition of the colour developing agent which consisted of a mixture of 2.5 $\mathrm{g} / \mathrm{L}$ sulfanilamide, $25 \mathrm{~mL} / \mathrm{L}$ of a $85 \%$ phosphoric acid solution and $0.25 \mathrm{~g} / \mathrm{L} \mathrm{N}$-(-1-naphthyl)-etylene diamine dihydrochloride to an aliquot of the sample. The absorbance was read at a wavelenght $543 \mathrm{~nm}$. The concentration was determined with the aid of a calibration curve. A DR2000 spectrophotometer (Hach Co. Loveland CO) was used.

\section{The ammonia concentration}

The ammonia concentration was determined using the distillation method (APHA et al., 2005). An aliquot of the sample was buffered with $25 \mathrm{~mL}$ of a solution that contained $9.5 \mathrm{~g} / \mathrm{L}$ sodium tetra borate and $88 \mathrm{~mL}$ $0.1 \mathrm{~N} \mathrm{NaOH}$, treated with $30 \%$ sodium hydroxide to increase the $\mathrm{pH}$ value above $\mathrm{pH}$ 9. The sample was then distilled on a Kjeltec system 1002 distillation unit. The distillate was collected in $2 \%$ boric acid solution and titrated to end point with $0.02 \mathrm{~N}$ sulphuric acid.

\section{TKN}

For the TKN analysis, an aliquot of the sample was first digested (Buchi) with $10 \mathrm{~mL}$ concentrated sulphuric acid and a TKN tablet (Merck) (potassium sulphate and cupric sulphate) at $360^{\circ} \mathrm{C}$. The resultant ammonia was determined as mentioned before (APHA et al., 2005).

COD

The COD concentration was determined according to the closed reflux, colorimetric method. An aliquot of the sample was treated with $1.5 \mathrm{~mL}$ digestion solution (which was a mixture of $10.216 \mathrm{~g} / \mathrm{L}$ potassium dichloromate, $167 \mathrm{~mL}$ concentrated sulphuric acid and $33.3 \mathrm{~g} / \mathrm{L}$ mercuric sulphate) and $3.5 \mathrm{~mL}$ concentrated sulphuric acid, and digested at $150{ }^{\circ} \mathrm{C}$ for two hours. After cooling, the absorbance of the samples was read at $600 \mathrm{~nm}$ using a spectrophotometer (Hach model: DR2000). The concentration was determined with the aid of a calibration curve (APHA et al., 2005).

All chemicals used were of analytical grade and obtained from major retailers.

\section{Data analysis}

The estimated interval of the mean (t-estimate) was calculated at $95 \%$ confidence level for the different parameters in the effluent from the different trials, at stable state conditions. Data Analysis Plus ${ }^{\mathrm{TM}} 2.12$ an add-in for Microsoft Excel was used to perform the data analysis. The results are reported as $\bar{x} \pm 1.96 \frac{s}{\sqrt{n}}$ (where $\bar{x}$ is the estimated mean, ó is the standard deviation and $n$ the number of samples (Keller and Warrack, 2000).

\section{RESULTS AND DISCUSSION}

The synthetic medium applied to the filter contained urea as the nitrogen source at different concentrations. It is known that urea will be hydrolysed rapidly by the enzyme urease to form ammonium ions according to the following reaction equation (Orhon and Artan, 1994):

$\left(\mathrm{NH}_{2}\right)_{2} \mathrm{CO}+2 \mathrm{H}_{2} \mathrm{O} \Leftrightarrow 2 \mathrm{NH}_{4}^{+}+\mathrm{CO}_{3}^{2-}$

The production of carbonate ions will increase the alkalinity of the liquid and thereby cause an increase in the $\mathrm{pH}$. The synthetic medium was buffered to a $\mathrm{pH}$ value of 7 with dihydrogen phosphate and hydrogen phosphate salts. The concentration of the phosphate in the synthetic medium was $1.0 \mathrm{~g} \mathrm{P} / \mathrm{L}$. The buffering capacity in urine is also because of the phosphate concentration which depends on a person's diet as the excess phosphate ingested is excreted in the urine (Sherwood, 2008). Wilsenach (2006) reported that urine contains $c a 1.0 \mathrm{~g} \mathrm{P} / \mathrm{p}$.d and the volume of urine excreted daily varies between $0.8-1.6 \mathrm{~L}$ (WHO, 2006), thus the phosphate concentration will vary between $0.62-1.25 \mathrm{~g}$ $\mathrm{P} / \mathrm{L}$ which is thus comparable to the buffer capacity of the synthetic medium. The equilibrium between the $\mathrm{HPO}_{4}^{2-}$ and $\mathrm{H}_{2} \mathrm{PO}_{4}^{-}$ions will buffer changes in $\mathrm{pH}$ until saturated (Sherwood, 2008). The effect of this phenomenon was observed when the initial $\mathrm{pH}$ values in the middle of the reactor $(0.75 \mathrm{~m}$ from the top) were compared during the different trails. The $\mathrm{pH}$ values steadily increased from 7.0 to $8.2 \pm 0.4,8.8 \pm 0.6,9.4 \pm 0.1$ and $9.2 \pm 0.6$ at 72, 145, 289 and $434 \mathrm{~g} \mathrm{~N} / \mathrm{m}^{2} / \mathrm{d}$, respectively (Table 1). 
The ammonium ions $\left(\mathrm{NH}_{4}^{+}\right)$produced during the hydrolysis of urea, will also be in equilibrium with ammonia $\left(\mathrm{NH}_{3}\right)$ according to the following reaction equation (Benefield et al., 1982):

$$
\mathrm{NH}_{3}+\mathrm{H}_{2} \mathrm{O} \Leftrightarrow \mathrm{NH}_{4}^{+}+\mathrm{OH}
$$

When the $\mathrm{pH}$ increases, the equilibrium of the reaction will shift to the left and ammonium ions will form ammonia gas. Ammonia gas is very insoluble in water and will escape to the atmosphere. The percentage ammonia that will volatilize is a function of $\mathrm{pH}$ and temperature and can be calculated from the following equation (MetCalf and Eddy, 2003):

$\% \mathrm{NH}_{3}=\frac{100}{1+\left[H^{+}\right] / K_{a}}$

$\mathrm{K}_{\mathrm{a}}=$ ionization constant for ammonia, which is dependent on the temperature.

The concentration of the ammonia that could theoretically have volatilized during the trails was calculated based on the initial $\mathrm{pH}$ values observed in the middle of the reactor during the different trials. These values were used for the calculation and not those of the effluent, as these would differ significantly due to the hydrolysis of urea in the top part of the reactor, increasing the $\mathrm{pH}$ and nitrification in the lower part of the reactor, decreasing the $\mathrm{pH}$ (Table 1). The volatilization at $2000 \mathrm{mg} \mathrm{N} / \mathrm{L}$ was $5 \%$ (at a $\mathrm{pH}$ value of 8.2 and $20^{\circ} \mathrm{C}$ ) compared to $19.8 \%$ at $4000 \mathrm{mg} \mathrm{N} / \mathrm{L}$ (at a $\mathrm{pH}$ value of 8.8) and $44 \%$ for both 8000 and $12000 \mathrm{mg}$ $\mathrm{N} / \mathrm{L}$ having similar $\mathrm{pH}$ values of 9.4 and 9.2, respectively (Table 2). The success of the removal of ammonia by the air stripping process (volatilization) depends largely on the air: liquid ratio applied in the process. An air: liquid ratio of 1:1660 is required to remove ammonia by the stripping process (WPCF, 1983). As the air was supplied at a rate of $1.0 \mathrm{Nm}^{3} / \mathrm{h}$ and the average dosing rate was ca $630 \mathrm{~mL} / \mathrm{d}$, the air: liquid ratio was 1:2.6 $\times 10^{-}$ ${ }^{5}$, thus the air supplied was significantly higher than the requirements.

In addition to ammonia being removed by volatilization, some of the ammonium ions will be assimilated by the bacteria to form new cell material. Microorganisms require nitrogen for growth. Heterotrophic organisms which grow on domestic waste water require carbon, nitrogen and phosphorous (expressed as $\mathrm{BOD}_{5}: \mathrm{N}: \mathrm{P}$ ) in a ratio of 100:5:1 (Orhon and Artan, 1994). However, the biomass yield for aerobic heterotrophic growth on pure glucose (carbon source used in this study) is higher than growth on

Table 1: The performance of the reactor at the different nitrogen loading rates

\begin{tabular}{|c|c|c|c|c|}
\hline $\mathrm{N}$ loading rate & $\begin{array}{r}72 \\
\mathrm{~g} \mathrm{~N} / \mathrm{m}^{2} / \mathrm{d}\end{array}$ & $\begin{array}{r}145 \\
\mathrm{~g} \mathrm{~N} / \mathrm{m}^{2} / \mathrm{d}\end{array}$ & $\begin{array}{r}289 \\
\mathrm{~g} \mathrm{~N} / \mathrm{m}^{2} / \mathrm{d}\end{array}$ & $\begin{array}{r}434 \\
\mathrm{~g} \mathrm{~N} / \mathrm{m}^{2} / \mathrm{d}\end{array}$ \\
\hline $\begin{array}{l}\mathrm{pH} \\
\text { Middle of reactor }\end{array}$ & $8.2 \pm 0.4$ & $8.8 \pm 0.6$ & $9.4 \pm 0.1$ & $9.2 \pm 0.6$ \\
\hline $\begin{array}{l}\text { pH effluent } \\
\text { Ammonia (mg N/L) } \\
\text { COD (mg COD/L) } \\
\text { Middle of reactor }\end{array}$ & $\begin{array}{r}7.4 \pm 0.4 \\
334.2 \pm 108.7 \\
2890.3 \pm 1264.3\end{array}$ & $\begin{array}{r}7.8 \pm 0.1 \\
285.5 \pm 9.1 \\
4291.0 \pm 710.3\end{array}$ & $\begin{array}{r}8.5 \pm 0.1 \\
1304.2 \pm 97.0 \\
4468 \pm 658.3\end{array}$ & $\begin{array}{r}8.3 \pm 0.2 \\
1538.0 \pm 385.5 \\
6372.7 \pm 2799.3\end{array}$ \\
\hline $\begin{array}{l}\text { COD (mg COD/L) } \\
\text { Effluent }\end{array}$ & $1802.3 \pm 569.0$ & $2300.3 \pm 757.2$ & $1425.5 \pm 484.4$ & $2549.2 \pm 1356.3$ \\
\hline $\begin{array}{l}\text { Nitrite (mg N/L) } \\
\text { Nitrate (mg N/L) }\end{array}$ & $\begin{array}{r}16.2 \pm 8.1 \\
196.8 \pm 58.3 \\
\end{array}$ & $\begin{array}{l}14.7 \pm 12.1 \\
24.0 \pm 23.2\end{array}$ & $\begin{array}{r}6.1 \pm 2.8 \\
64.7 \pm 40.6 \\
\end{array}$ & $\begin{array}{l}0.5 \pm 0.5 \\
6.1 \pm 4.8 \\
\end{array}$ \\
\hline
\end{tabular}

Table 2: The theoretical fate of the ammonium, in $\mathrm{mg} \mathrm{N} / \mathrm{L}$, at the different nitrogen loading rates

\begin{tabular}{|c|c|c|c|c|}
\hline Loading rate, g $\mathrm{N} / \mathrm{m}^{2} / \mathrm{d}$ & 72 & 145 & 289 & 434 \\
\hline Concentration, mg N/L & 2000 & 4000 & 8000 & 12000 \\
\hline Volatile ammonia (mg N/L) & 117 & 792 & 3508 & 5262 \\
\hline Assimilation in biomass (mg N/L) & 1182 & 1182 & 1182 & 1182 \\
\hline
\end{tabular}


M. A. A. Coetzee et al.

Table 3: Calculated fate of nitrogen according to effluent analysis, in $\mathrm{mg} \mathrm{N} / \mathrm{L}$ at the different nitrogen loading rates

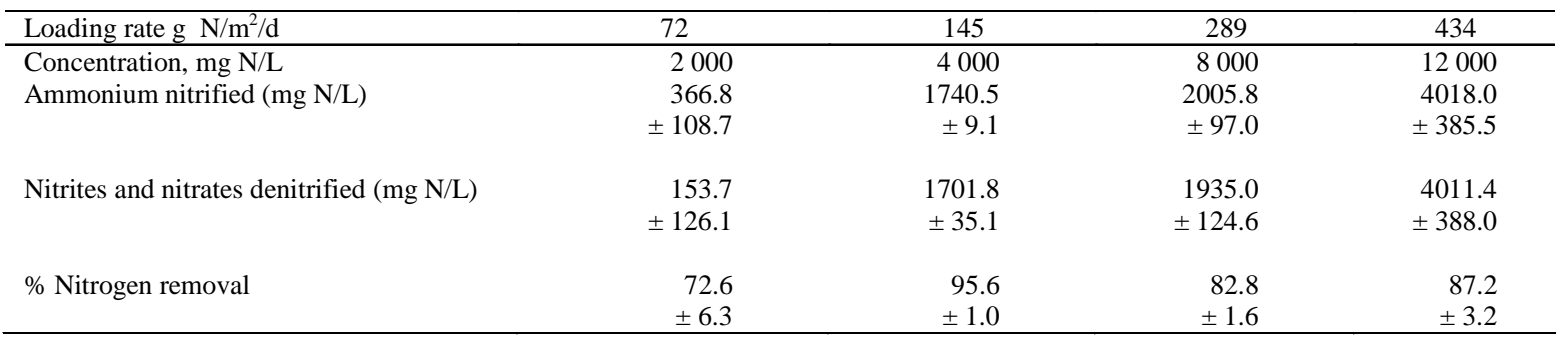

domestic waste water. The $\mathrm{Y}_{\mathrm{H}}$ ( $\mathrm{e}^{-}$. e biomass/ $\mathrm{e}^{-}$. e substrate) for domestic waste water is $0.66 \mathrm{e}$. e biomass/ $\mathrm{e}^{-}$. e substrate compared to the $0.79 \mathrm{e}^{-}$. e biomass/ e. e substrate for glucose (Orhon and Artan, 1994). The nitrogen requirements can be calculated from stoichiometric reaction equations developed by using the concept of half-reactions (Grady and Lim, 1980; Orhon and Artan, 1994). For heterotrophic, aerobic growth with glucose as carbon source and electron donor, the three half reactions will be:

$$
\begin{aligned}
& \mathrm{R}_{\mathrm{d}}=\frac{1}{24} \mathrm{C}_{6} \mathrm{H}_{12} \mathrm{O}_{6}+\frac{1}{4} \mathrm{H}_{2} \mathrm{O} \rightarrow \frac{1}{4} \mathrm{CO}_{2}+\mathrm{H}^{+}+\mathrm{e}^{-} \\
& R_{c}=\frac{1}{20} \mathrm{C}_{5} \mathrm{H}_{7} \mathrm{NO}_{2}+\frac{9}{20} \mathrm{H}_{2} \mathrm{O} \rightarrow \\
& \frac{1}{5} \mathrm{CO}_{2}+\frac{1}{20} \mathrm{HCO}_{3}^{-}+\frac{1}{20} \mathrm{NH}_{4}^{+}+\mathrm{H}^{+}+e^{-} \\
& \mathrm{R}_{\mathrm{a}}=\frac{1}{2} \mathrm{H}_{2} \mathrm{O} \rightarrow \frac{1}{4} \mathrm{O}_{2}+\mathrm{H}^{+}+\mathrm{e}^{-}
\end{aligned}
$$

Thus for glucose, where $\mathrm{Y}_{\mathrm{NH}}=0.79 \mathrm{e}^{-}$. e biomass/ $\mathrm{e}^{-}$. e substrate, the overall stoichiometric reaction equation for bacterial growth is:

$\mathrm{R}_{0}=\mathrm{R}_{\mathrm{d}}-0.79 \mathrm{R}_{\mathrm{c}}-0.21 \mathrm{R}_{\mathrm{a}}$

$\mathrm{R}_{0}=$ the overall stoichiometric reaction

$\mathrm{R}_{\mathrm{d}}=$ Reaction for electron donor

$\mathrm{R}_{\mathrm{c}}=$ Reaction for bacterial cell synthesis

$\mathrm{R}_{\mathrm{a}}=$ Reaction for electron acceptor

By applying equation (7) the amount of ammonia required per e-. e substrate (expressed as $\mathrm{N}$ ) can be calculated as follows:

$$
0.79 \times \frac{1}{20} \times 14=0.533 \mathrm{~g} \mathrm{~N}
$$

As $1 \mathrm{e}$ - e substrate is equivalent to $8 \mathrm{~g}$ COD (Orhon and Artan, 1994) the COD: $N$ ratio can be calculated as follows:

$$
\frac{\mathrm{COD}}{\mathrm{N}}=\frac{8 \mathrm{~g} \mathrm{COD}}{0.553 \mathrm{~g} \mathrm{~N}}=14.47
$$

Since $16 \mathrm{~g} / \mathrm{L}$ glucose (concentration of the glucose used in the synthetic medium) has a theoretical COD value of $17.1 \mathrm{~g} / \mathrm{L}$, the amount of $\mathrm{N}$ required for growth will be $1.182 \mathrm{~g} / \mathrm{L}$ (Table 2). The amount of nitrogen required for synthesis of new biomass could therefore account for $59.1 \%, 29.6 \%, 14.8 \%$ and $9.9 \%$ of the initial nitrogen loss in the system during the trails at nitrogen loading rates of 72, 145, and 289 and $434 \mathrm{~g} \mathrm{~N} /$ $\mathrm{m}^{2} / \mathrm{d}$, respectively.

The nitrification capacity (the residual concentration of ammonium after volatilization and biomass production) i.e. the ammonium, available to be nitrified, was calculated, at the different nitrogen loading rates according to the following formula and the results given in Table 2:

$\mathrm{N}_{\mathrm{c}}=\mathrm{N}_{\mathrm{t}}-\mathrm{N}_{\mathrm{s}}-\mathrm{N}_{\mathrm{v}}$

$\mathrm{N}_{\mathrm{C}}$ = nitrification capacity, mg $\mathrm{N} / \mathrm{L}$

$\mathrm{N}_{\mathrm{t}}=$ TKN concentration in the feed, mg N/L

$\mathrm{N}_{\mathrm{s}}$ = concentration of the nitrogen that is assimilated to form new biomass in $\mathrm{mg} \mathrm{N} / \mathrm{L}$

$\mathrm{N}_{\mathrm{v}}$ = concentration of the nitrogen that was volatilized in $\mathrm{mg} \mathrm{N} / \mathrm{L}$.

The nitrification capacity increased as the nitrogen load increased. The theoretical nitrogen removal for biomass production was constant and the major factor influencing the increase in nitrification capacity was volatilization driven by the $\mathrm{pH}$. The volatilization at 2000 $\mathrm{mg} \mathrm{N} / \mathrm{L}$ was $117 \mathrm{mg} \mathrm{N} / \mathrm{L}$ (at a pH value of 8.2) compared to $792 \mathrm{mg} \mathrm{N} / \mathrm{L}$ at $4000 \mathrm{mg} \mathrm{N} / \mathrm{L}$ (at a pH value of 8.8), 3508 $\mathrm{mg} \mathrm{N} / \mathrm{L}$ at 8000 and $5262 \mathrm{mg} \mathrm{N} / \mathrm{L}$ at $12000 \mathrm{mg} \mathrm{N} / \mathrm{L}$. Dueto 
increased volatilization at the higher nitrogen loading rates the nitrification capacity did not increase proportionally to the increase in nitrogen loading (Table 2). The following chemical reaction occurs during nitrification (MetCalf and Eddy, 2003):

$$
\mathrm{NH}_{4}^{+}+2 \mathrm{O}_{2} \Leftrightarrow \mathrm{NO}_{3}^{-}+2 \mathrm{H}^{+}+\mathrm{H}_{2} \mathrm{O}
$$

Because of the production of hydrogen ions, alkalinity decreases and the $\mathrm{pH}$ of the liquid declines (WRC, 1984). The pH decreased in the lower part of the reactor during all the trails, as the $\mathrm{pH}$ values at all the nitrogen loading rates were lower than that observed from the middle of the reactor (Table 1). This decrease in $\mathrm{pH}$ together with the appearance of nitrate and nitrite ions in the effluent supply evidence that nitrification had occurred. The actual ammonium concentration was determined in the effluent and the concentration nitrified calculated by using the difference between the nitrification capacity (the theoretical maximum that can be nitrified $-\mathrm{N}_{\mathrm{c}}$ ) and the ammonium concentration in the effluent at all the nitrogen loading rates (Table 2). As the nitrogen loading rate increased, the concentration of the ammonia that was nitrified increased progressively from 366.8 mg N/L, 1740.5 mg N/L, $2005.8 \mathrm{mg}$ N/L and $4018 \mathrm{mg}$ $\mathrm{N} / \mathrm{L}$ at 72, 145, 289 and $434 \mathrm{~g} \mathrm{~N} / \mathrm{m}^{2} / \mathrm{d}$, respectively. However the highest percentage ammonia was nitrified at a nitrogen loading rate of $145 \mathrm{~g} \mathrm{~N} / \mathrm{m}^{2} / \mathrm{d}$, namely $85 \%$, while the lowest percentage was observed at $72 \mathrm{~g} \mathrm{~N} / \mathrm{m}^{2} / \mathrm{d}$, namely $57 \%$. The weak performance of the reactor at $72 \mathrm{~g} \mathrm{~N} / \mathrm{m}^{2} / \mathrm{d}$ could be explained from the observed results of ammonia, $\mathrm{pH}$, nitrate and nitrite concentrations during that trail (Fig. 3). Between approximately 50 days and 118 days of operation, the ammonia concentration decreased to $63 \mathrm{mg} \mathrm{N} / \mathrm{L}$ while the $\mathrm{pH}$ decreased to $\mathrm{pH}$ 6. The nitrite concentration increased to a high of ca $600 \mathrm{mg} \mathrm{N} / \mathrm{L}$ and very little nitrate was formed. After approximately 118 days, the $\mathrm{pH}$ and ammonia concentration increased again and stabilized at $\mathrm{pH}$ $7.4 \pm 0.4$, an ammonium concentration of $334.2 \pm$ $108.7 \mathrm{mg} \mathrm{N} / \mathrm{L}$ and the nitrate concentration at 196.8 $\pm 58.3 \mathrm{mg} \mathrm{N} / \mathrm{L}$. A possible explanation for the near absence of nitrates could be attributed to the fact that the bacteria involved in the second step of nitrification, the Nitrobacter species, are inhibited when the $\mathrm{pH}$ decrease below 7 (Anthonison et al., 1976). It would have been a definite advantage to have extended the running time of this reactor to ascertain stable state conditions.

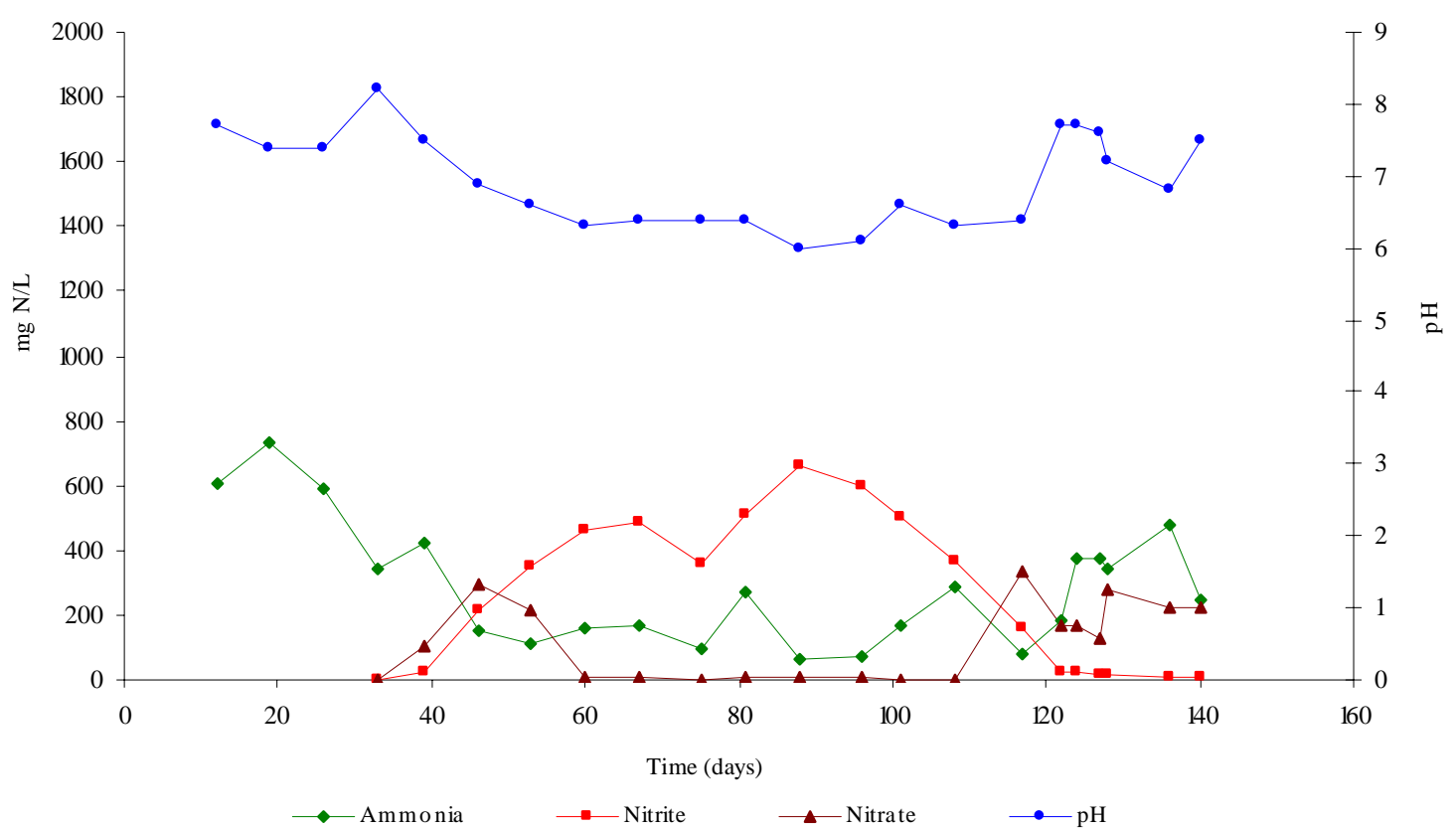

Fig. 3: The performance of the biological filter at a nitrogen loading rate of $72 \mathrm{~g} \mathrm{~N} / \mathrm{m}^{2} / \mathrm{d}$ with regards to nitrogen species and $\mathrm{pH}$ 
In contrast to the above, the first step of nitrification, the oxidation of ammonia, is inhibited if the $\mathrm{pH}$ is higher than 9 (Anthonison et al., 1976). This can probably explain the weaker nitrification rate at the higher nitrogen loading rates where the $\mathrm{pH}$ increased to above 9 , as the percentage ammonia that was nitrified, was $61 \%$ at $289 \mathrm{~g} \mathrm{~N} / \mathrm{m}^{2} / \mathrm{d}$ and $72 \%$ at $434 \mathrm{~g} \mathrm{~N} / \mathrm{m}^{2} / \mathrm{d}$ compared to $85 \%$ obtained at a nitrogen loading rate of $145 \mathrm{~g} \mathrm{~N} / \mathrm{m}^{2} / \mathrm{d}$ (Tables 2 and 3).

Near complete denitrification was observed at all nitrogen loading rates, except at the lowest nitrogen loading rate of $72 \mathrm{~g} \mathrm{~N} / \mathrm{m}^{2} / \mathrm{d}$. There, only $36 \%$ of the ammonia concentration that was nitrified, was denitrified and the concentration of the nitrates were $196.8 \pm 58.3 \mathrm{mg} \mathrm{N} / \mathrm{L}$ and that of the nitrites were 16.2 $\pm 8.1 \mathrm{mg} \mathrm{N} / \mathrm{L}$ (Table 1 ). At the higher nitrogen loading rates the affectivity increased and the denitrification rate was greater than $96 \%$.

Two factors which have an influence on the rate of denitrification are the presence of dissolved oxygen, which will inhibit denitrification and the availability of a carbon source (WRC, 1984). Although air was supplied to the reactor, denitrification occurred as the biofilm was probably thick enough to maintain anaerobic conditions within, as also reported in literature (Iwai and Kitoa, 1994, Biesterfeld et al., 2003). The other factor which has a major influence on the denitrification rate is the availability of carbon. The C:N ratios in this study decreased as the nitrogen loading rate increased. Based on the initial loading rates, the $\mathrm{C}: \mathrm{N}$ ratios were $8.6: 1,4.3: 1,2.1: 1$ and $1.4: 1$ at 72, 145, 289 and $434 \mathrm{~g} \mathrm{~N} / \mathrm{m}^{2} / \mathrm{d}$, respectively. However, most of the nitrification occurred in the lower part of the reactor so the ammonium concentration nitrified and the COD concentration in the middle of the reactor was used to determine the COD: $\mathrm{NO}_{3}-\mathrm{N}$ ratios during the trials at different nitrogen loading rates. The ratios were $7.5: 1 ; 2.6: 1$, 2.2:1 and 1.5:1 at 72, 145, 289 and $434 \mathrm{~g} \mathrm{~N} / \mathrm{m}^{2} / \mathrm{d}$, respectively. The $\mathrm{C}: \mathrm{N}$ ratios at the higher nitrogen loading rates decreased below the $C: N$ ratios reported in literature to yield successful denitrification. The type of carbon source used will have an influence of the $\mathrm{C}: \mathrm{N}$ ratio required to achieve denitrification. Chiu and Chung (2003) reported optimal C:N ratios between 2.6 and 5.5 for different carbon sources. There is two possible explanations for the good denitrification rates at the low $\mathrm{C}: \mathrm{N}$ ratios at the nitrogen loading rates of 289 and $434 \mathrm{~g} \mathrm{~N} / \mathrm{m}^{2} /$ d. Firstly, Chiu and Chung (2003) reported that denitrifiying bacteria become dominant at higher nitrate concentrations and that the carbon requirements to satisfy denitrification will decrease as the nitrate concentration increase. Secondly bacteria may oxidize nitrite, which is formed as intermediate compounds during both nitrification and denitrification and as these processes occurred simultaneously in the bottom part of the reactor. According to Chung et al. (2007), by using nitrite during denitrification, $40 \%$ less carbon is required to achieve denitrification.

Nitrogen was removed at all the nitrogen loading rates. The best total nitrogen removal was obtained at $145 \mathrm{~g} \mathrm{~N} / \mathrm{m}^{2} /$ d, with $92 \%$ of which $29.6 \%$ was incorporated into biomass, $19.8 \%$ volatilized and $42.6 \%$ denitrified. At a nitrogen loading rate of $289 \mathrm{~g} \mathrm{~N} / \mathrm{m}^{2} / \mathrm{d}$ the total nitrogen removal was $82.7 \%(14.8 \%$ incorporated into biomass, $43.8 \%$ volatilized and $24.2 \%$ denitrified) and at a nitrogen loading rate of $434 \mathrm{~g} \mathrm{~N} / \mathrm{m}^{2} /$ d, $87.2 \%$ total nitrogen was removed (9.9\% incorporated into biomass, $43.8 \%$ volatilized and $33.4 \%$ denitrified). The weakest performance was obtained at a nitrogen loading rate of $72 \mathrm{~g} \mathrm{~N} / \mathrm{m}^{2} / \mathrm{d}$ where the total nitrogen removal was only $72.7 \%$ (59.1 \% incorporated into biomass, $5.9 \%$ volatilized and $7.7 \%$ denitrified). Should the biological filter be installed beneath a ventilated improved pit latrine, the nitrogen loading rate on the biological filter can be calculated as follows:

$\mathrm{NLR}=\frac{\mathrm{N}_{\text {anual }} \times \mathrm{P}}{365 \times \mathrm{A}}$

$\mathrm{NLR}=$ nitrogen loading rate on the proposed system, g N/m²/d.

$\mathrm{N}_{\text {anual }}=$ annual nitrogen loading rate excreted per person, $\mathrm{g} \mathrm{N}$. $\mathrm{P}=$ number of people that use the pit latrine

$\mathrm{A}=$ the surface area of the proposed biological filter $=$ $0.25 \mathrm{~m}^{2}$

By using equation 12 and taking into account the variations, given in literature, for nitrogen excreted daily (depending on diet) namely between $2.1 \mathrm{~kg} \mathrm{~N} / \mathrm{p} / \mathrm{y}$ and $4.0 \mathrm{~kg} \mathrm{~N} / \mathrm{p} / \mathrm{y}$ (WHO, 2006), the nitrogen loading rate on the pit latrine could vary between 138 and $263 \mathrm{~g} \mathrm{~N} / \mathrm{m}^{2} /$ $\mathrm{d}$. The results obtained in this study, examining the nitrogen removal efficiency of a laboratory scale biological filter (with dimensions proportional to that of the proposed system) charged with between 72 and 
$434 \mathrm{~g} \mathrm{~N} / \mathrm{m}^{2} / \mathrm{d}$, showed high nitrogen removal and should therefore be able to remove nitrogen in the range of 138 and $263 \mathrm{~g} \mathrm{~N} / \mathrm{m}^{2} / \mathrm{d}$ effectively.

\section{CONCLUSION}

Nitrogen removal in the form of urea was obtained in a biological filter at nitrogen loading rates of 72 , 145, 289 and $434 \mathrm{~g} \mathrm{~N} / \mathrm{m}^{2} / \mathrm{d}$, applied at a very low hydraulic loading rate $\left(35.7 \mathrm{~L} / \mathrm{m}^{2} / \mathrm{d}\right)$ and a relative high organic loading rate $\left(0.3 \mathrm{~kg} \mathrm{BOD} / \mathrm{m}^{3} / \mathrm{d}\right)$. The nitrogen was removed by a combination of assimilation, volatilization, nitrification and denitrification processes. The biological filter showed effective nitrogen removal between 72 and $434 \mathrm{~g} \mathrm{~N} / \mathrm{m}^{2} / \mathrm{d}$ and the best total nitrogen removal was obtained at $145 \mathrm{~g}$ $\mathrm{N} / \mathrm{m}^{2} / \mathrm{d}$, namely $92 \%$. These results suggest that it should be possible to remove nitrogen effectively using a biological filter beneath a modified ventilated improved pit latrine.

\section{ACKNOWLEDGEMENTS}

The authors gratefully acknowledge the financial assistance from Tshwane University of Technology towards the completion of this project.

\section{REFERENCES}

Anthonisen, A. C.; Loehr, R. C.; Prakasam, T. B. S.; Srinath, E. G., (1976). Inhibition of nitrification of ammonia and nitrous acid., J. Water Pollut. Fed., 48 (5), 835 - 852 (18 pages).

APHA; AWWA; WEF, (2005). Standard methods for the examination of water and waste water, $21^{\text {th }} \mathrm{Ed}$. American Public Health Association, Washington, D.C.

Babel, S.; Sae-Tang, J.; Pecharaply, A., (2009). Anaerobic codigestion of sewage and brewery sludge for biogas production and land application. Int. J. Environ. Sci. Tech., 6 (1), 131140 (10 pages).

Benefield, L. D.; Judkins, J. F.; Weand, B. L., (1982). Processes Chemistry for Water and Wastewater Treatment. PrenticeHall, Inc., Englewood Cliffs, New Jersey.

Biesterfield, S.; Farmer, G.; Figueroa, L.; Parker, D.; Russell, P., (2003). Quantification of denitrification potential in carbonaceous trickling filters., Water Res., 37 (16), 4011 4017 (7 pages).

Cheng, B.; Hu, C. W.; Zhao, Y. J., (2011). Effects of plants development and pollutant loading on performance of vertical subsurface flow constructed wetlands. Int. J. Environ. Sci. Tech., 8 (1), 177-186 (10 pages).

Chenini, I.; Khemiri, S., (2009). Evaluation of ground water quality using multiple linear regression and structural equation modeling. Int. J. Environ. Sci. Tech., 6 (3), 509-519 (11 pages )

Chiu, Y.; Chung, M., (2003). Determination of optimal COD/ nitrate ratio for biological denitrification., Int. Biodeterior. Biodegrad., 51 (1), 43 - 49 (7 pages).
Chung, J.; Bae, W.; Lee, Y.; Rittmann, B. E., (2007). Shortcut biological nitrogen removal in hybrid biofilm/suspended growth reactors. Process Biochem., 42 (3), 320 - 328 (9 pages).

DWAF, (2003). A protocol to manage the potential of groundwater contamination from on site sanitation, $2^{\text {nd }} \mathrm{Ed}$. Department of Water Affairs and Forestry, Pretoria, South Africa.

Dzwairo, B.; Hoko, Z.; Love, D.; Guzha, E., (2006). Assessment of the impacts of pitlatrines on groundwater quality in rural areas: A case study from Marondera district, Zimbabwe., Phys. Chem. Earth., 31 (15-16), 779 - 788 (10 pages).

Geigy, J. R., (1962). Documenta Scientific tables, 6 ${ }^{\text {th }}$ Ed. S. A. Basle Switerland.

Grady, C. P. L.; Lim, H. C., (1980). Biological Treatment Processes. Marcel Dekker, Inc, New York.

Iwai, S.; Kitao, T., (1994). Wastewater treatment with microbial films. Technomic Publishing Co., Inc., Lancaster.

Keller, G.; Warrack, B., (2000). Statistics for Management and Economics, $5^{\text {th }}$ Ed. Duxbury Thomson Learning, New York.

Koné, D.; Strauss, M., (2004). Low-cost options for treating faecal sludges (FS) in developing countries - challenges and performance. 6th International IWA Specialist Group Conference on Waste Stabilization Ponds, Avignon, France, 27 Sept - 1 Oct.

Lu, X. M.; Huang, M. S., (2010). Nitrogen and phosphorus removal and physiological response in aquatic plants under aeration conditions. Int. J. Environ. Sci. Tech., 7 (4), 665674 (10 pages).

Metcalf and Eddy Inc., (2003). Wastewater Engineering, Treatment, Disposal and Reuse, 4th Ed. McGraw-Hill, New York.

Miller, R.; Wideman, O., (1956). Bestimnung des Nitrat-Ions in Wasser., Wasser, 22, 2471-2472 (2 pages).

Montagero, A.; Strauss, M., (2002). Faecal sludge treatment. Available at: http://www.eawag.ch/organisation/abteilungen/ sandec/publikationen/publications_ewm/downloads_ewm/ IHE_lecture_notes.pdf. Accessed: 27/11/2008.

Nouri, J.; Karbassi, A. R.; Mirkia, S., (2008). Environmental management of coastal regions in the Caspian Sea. Int. J. Environ. Sci. Tech., 5 (1), 43-52 (10 pages).

Nwuche, C. O.; Ugoji, E. O., (2010). Effect of co-existing plant specie on soil microbial activity under heavy metal stress. Int. J. Environ. Sci. Tech., 7 (4), 697-704 (8 pages).

Okafor, E. C.; Opuene, K., (2007). Preliminary assessment of trace metals and polycyclic aromatic hydrocarbons in the sediments. Int. J. Environ. Sci. Tech., 4 (2), 233-240 (8 pages).

Orhon, D.; Artan, N., (1994). Modeling of activated sludge systems. Technomic Publishing Co., Inc., Lancaster.

Pickford, J., (1995). Lowcost sanitation. A survey of practical experience. Intermediate Technology Publications, London.

Sherwood, L., (2008). Human physiology: From cells to systems, $7^{\text {th }}$ Ed. Brooks/ Cole Cengage Learning, Belmont, USA.

Suthar, S.; Bishnoi, P.; Singh, S.; Mutiyar, P. K.; Nema, A. K.; Patil, N. S., (2009). Nitrate contamination in groundwater of some rural areas of Rajasthan, Indian. J. Hazard. Mater., 171 (1-3), 189-199 (11 pages).

Terblance, A. P. S., (1991). Health hazards of nitrate in drinking water., Water SA, 17 (1), 77 - 82 (6 pages). 
Tredoux, G.; Talma, A. S.; Engelbrecht, J. F. P., (2000). The increasing nitrate hazard in groundwater in the rural areas. In Proceedings of WISA 2000 Biennial Conference. Sun City, South Africa, 28 May - 1 June.

WHO, (1992). A guide to the development of on-site sanitation. World Health Organization Press, Geneva, Switzerland.

WHO, (2006). Guidelines for the safe use of wastewater, excreta and greywater, vol 4: Excreta and greywater used in agriculture. World Health Organization Press, Geneva, Switzerland.

WHO, (2009). 10 Facts on sanitation. Available at: hppt:// www.who.int/features/factfiles/sanitation/facts/en/ index.html. Accessed: 7/23/2009.

WHO; UNICEF, (2008). Progress on drinking water and sanitation. WHO/ UNICEF Joint Monitoring Programme.
World Health Organization and United Nations Children's Fund, Geneva, New York.

Wilsenach, J. A., (2006). Treatment of source separated urine and its effects on wastewater systems. Thesis Delft University of Technology, The Netherlands.

WPCF, (1983). Nutrient control. Manual of Practice FD-7: Facilities design. Water Pollution Control Federation, 601 Wythe Street, Alexandria, VA 22314-1994.

WRC, (1984). Manual for the design and operation of nutrient removal plants. Water Research Commission, Pretoria.

Zingoni, E.; Love, D.; Magadza, C.; Moyce, W.; Musiwa, K., (2005). Effects of semi-formal urban settlement on groundwater quality Epworth, Zimbabwe: Case study and groundwater quality zoning., Phys. Chem. Earth., 30 (1116), 680 - 688 (9 pages).

\section{AUTHOR (S) BIOSKETCHES}

Coetzee, Martha, Anna Aletta, M.Sc., Senior lecturer in the Department Environment, Water and Earth Sciences, Tshwane University of Technology, Pretoria, South Africa. E-mail: coetzeemaa@tut.ac.za

Van der Merwe, Magaretha Petronella, Ph.D., Professor in the Department Biotechnology and Food Technology, Tshwane University of Technology, Pretoria, South Africa. E-mail: RouxVanDerMerweMP@tut.ac.za

Badenhorst, Jacqueline, Ph.D., Senior lecturer in the Department Biotechnology and Food Technology, Tshwane University of

Technology, Pretoria, South Africa. E-mail: BadenhorstJ@tut.ac.za 